\title{
Shrubland Lepidoptera of southern New England and southeastern New York: ecology, conservation, and management
}

\author{
David L. Wagner ${ }^{\mathrm{a}, *}$, Michael W. Nelson ${ }^{\mathrm{a}, \mathrm{b}}$, Dale F. Schweitzer ${ }^{\mathrm{c}}$ \\ ${ }^{a}$ Department of Ecology and Evolutionary Biology, University of Connecticut, Storrs, CT 06269, USA \\ ${ }^{\mathrm{b}}$ Natural Heritage and Endangered Species Program, Massachusetts Division of Fisheries and Wildlife, Westborough, MA 01581, USA \\ ${ }^{\mathrm{c}}$ NatureServe, 1761 Main Street, Port Norris, NJ 08349, USA
}

\begin{abstract}
Sandplain and ridgetop pitch pine (Pinus rigida)-scrub oak (Quercus ilicifolia) barrens and other shrub-dominated natural communities (e.g., heathlands and maritime shrublands) are important habitats for rare Lepidoptera (moths and butterflies) in southern New England and southeastern New York. Fifty-six species of conservation concern representing 11 families of Lepidoptera are recognized as dependent on shrubland habitats in this region, including $23 \%$ of Connecticut's state-listed Lepidoptera and $41 \%$ of state-listed moths and butterflies in Massachusetts. Sixteen (29\%) of these 56 species utilize scrub oak as a larval host and eight species (14\%) use lowbush blueberries (Vaccinium angustifolium and V. pallidum). In addition to Lepidoptera, a wide diversity of other invertebrates is dependent on pine barrens and other shrublands. The importance of these habitats results from unique edaphic conditions and temperature regimes, as well as the structure, species composition, and phenology of the plant community. Pine barrens and other shrublands in the northeastern United States are threatened by destruction and fragmentation, as well as fire exclusion and other alterations of natural disturbance regimes. Active management, including the application of prescribed fire, mechanical cutting, or a combination of the two, is critical to the maintenance of habitat structure and species composition in barrens and other shrublands within human-dominated landscapes of the northeastern United States.
\end{abstract}

(C) 2003 Elsevier B.V. All rights reserved.

Keywords: Invertebrate conservation; Lepidoptera; Pitch pine-scrub oak barrens; Natural disturbance; Prescribed fire

\section{Introduction}

In this review, we discuss 56 rare species of Lepidoptera (Table 1) associated with shrubland habitats in a portion of the northeastern United States: southern New England (Connecticut, Rhode Island, Massachusetts, and southern portions of Vermont, New Hampshire, and Maine) and southeastern New York (Long Island and the Albany Pine Bush). We provide

\footnotetext{
* Corresponding author. Tel.: +1-860-486-2139.

E-mail address: david.wagner@uconn.edu (D.L. Wagner).
}

information on known habitat preferences, host plant associations, and global and state conservation status ranks. The 56 species of conservation concern are associated with five shrubland communities in particular: sandplain pitch pine (Pinus rigida)-scrub oak (Quercus ilicifolia) barrens, ridgetop pitch pine-scrub oak barrens, scrub oak shrublands, heathlands, and maritime shrublands (see Fig. 1). Scrub oak shrublands and heathlands tend to occur as smaller-scale openings within a landscape mosaic of pitch pinescrub oak barrens. Thus most shrubland Lepidoptera of conservation concern in southern New England and 
Table 1

Rare shrubland Lepidoptera and their habitat and host plant associations in southern New England and southeastern New York

\begin{tabular}{lll}
\hline Species, authority, family & $\begin{array}{l}\text { Habitat(s) in southern New England } \\
\text { and southeastern New York }\end{array}$ & $\begin{array}{l}\text { Larval host plant(s) in southern } \\
\text { New England and southeastern New York }\end{array}$ \\
\hline $\begin{array}{l}\text { Abagrotis brunneipennis } \\
\text { (Grote) (Noctuidae) }\end{array}$ & $\begin{array}{l}\text { Sandplains and occasionally ridgetops; } \\
\text { associated with lowbush blueberry }\end{array}$ & Vaccinium spp. \\
Acronicta albarufa Grote (Noctuidae) & $\begin{array}{l}\text { Xeric, open pitch pine-scrub oak barrens } \\
\text { and scrub oak thickets on sandy soil; } \\
\text { may have been less stenotopic historically }\end{array}$ & Quercus ilicifolia, possibly other Quercus spp. \\
Acronicta lanceolaria & $\begin{array}{l}\text { Pitch pine-scrub oak barrens; occasionally } \\
\text { other shrubland habitats; bogs northward }\end{array}$ & $\begin{array}{l}\text { Polyphagous; recorded hosts include Larix, } \\
\text { Lespedeza, Pinus, Quercus ilicifolia, } \\
\text { Rubus, Spiraea, Vaccinium, etc. }\end{array}$ \\
Anacampsis lupinella Busck & Xeric, open oak woodland, pitch pine-scrub & $\begin{array}{l}\text { Lupinus perennis } \\
\text { (Goctuidae) }\end{array}$
\end{tabular}

(Gelechiidae)

Anisota stigma (Fabricius)

(Saturniidae)

\section{Apharetra dentata \\ (Grote) (Noctuidae)}

Apodrepanulatrix liberaria

(Walker) (Geometridae)

Callophrys irus (Godart)

(Lycaenidae)

Callophrys polios (Cook and Watson) (Lycaenidae)

Cameraria castaneaeella (Chambers) (Gracillariidae)

Catocala badia Grote and Robinson (Noctuidae)

Catocala herodias gerhardi Barnes and Benjamin (Noctuidae)

Catocala jair ssp. 2

(Noctuidae)

Catocala muliercula Guenée (Noctuidae)

Catocala sp. 1 near jair (Noctuidae)

Catocala sp. 3 near ilia (Noctuidae)

\section{Cerma cora Hübner}

(Noctuidae)

Chaetaglaea cerata Franclemont (Noctuidae) oak barrens, and other disturbance-dependent habitats with lupine

Xeric coastal sandplain communities such as scrub oak thickets and open pitch pine-scrub oak barrens; also dry, open oak/pine woodland, especially southward Pitch pine-scrub oak barrens on sandplains or rocky summits and ridges (associated with lowbush blueberry); also acidic bogs and swamps with ericaceous vegetation Xeric, open habitats on sandy or rocky soil with New Jersey tea, including pitch pine-scrub oak barrens and associated sandplain communities, rocky outcrops and ridges Xeric and open, disturbance-dependent habitats on sandy (occasionally rocky) soil, including openings in pitch pine-scrub oak barrens and similar anthropogenic habitats such as powerline cuts, railways, old sand/gravel pits, and airports

Pitch pine-scrub oak barrens and other open habitats with bearberry

Pitch pine-scrub oak barrens and open oak woodlands

Maritime shrublands and other coastal plain habitats with bayberry

Pitch pine-scrub oak barrens and especially scrub oak thickets; also rocky summits and ridges with scrub oak

Xeric, open pitch pine-scrub oak barrens (e.g., the Long Island dwarf pine plains) Maritime shrublands and other coastal plain habitats with bayberry

Xeric, open pitch pine-scrub oak barrens Sandplain pitch pine-scrub oak barrens, especially in scrub oak thickets; also dry, open oak/pine woodland, especially southward Sandplain pitch pine-scrub oak barrens; less stenotopic elsewhere

Pitch pine-scrub oak barrens and heathlands on sandplains or rocky ridges and summits; occasionally other shrublands
Quercus spp., especially Q. ilicifolia and $Q$. prinoides

Vaccinium spp. preferred, also Kalmia polifolia and possibly other ericads

Ceanothus americanus

Baptisia tinctoria, Lupinus perennis

Arctostaphylos uva-ursi

Quercus ilicifolia

Myrica spp., especially M. pensylvanica

Quercus ilicifolia

Quercus ilicifolia

Myrica spp., especially M. pensylvanica

Quercus ilicifolia, possibly other Quercus spp. Quercus ilicifolia

Prunus pensylvanica

Undocumented, but probably polyphagous; captive larvae accept Prunus spp., Quercus ilicifolia, and Vaccinium spp. 
Table 1 (Continued)

\begin{tabular}{lll}
\hline Species, authority, family & $\begin{array}{l}\text { Habitat(s) in southern New England } \\
\text { and southeastern New York }\end{array}$ & $\begin{array}{l}\text { Larval host plant(s) in southern } \\
\text { New England and southeastern New York }\end{array}$ \\
\hline $\begin{array}{l}\text { Chaetaglaea tremula } \text { (Harvey) } \\
\text { (Noctuidae) }\end{array}$ & $\begin{array}{l}\text { Pitch pine-scrub oak barrens and heathlands } \\
\text { on sandplains or rocky ridges and summits; } \\
\text { occasionally other shrublands }\end{array}$ & $\begin{array}{l}\text { Probably polyphagous; documented hosts } \\
\text { include Comptonia peregrina, } \\
\text { Puercus spp., and Vaccinium } \text { spp. }\end{array}$ \\
$\begin{array}{ll}\text { Pitch pine-scrub oak barrens and open } \\
\text { oak woodlands, often sites that have } \\
\text { burned in the previous decade }\end{array}$ & $\begin{array}{l}\text { Captive larvae have been reared } \\
\text { on fungus (e.g., Poria) }\end{array}$ \\
Cicinnus melsheimeri (Harris) & $\begin{array}{l}\text { Sandplain pitch pine-scrub oak barrens, } \\
\text { especially in scrub oak thickets }\end{array}$ & Quercus ilicifolia
\end{tabular}

Cingilia catenaria (Drury)

(Geometridae)

\section{Datana contracta Walker}

(Notodontidae)

Diarsia rubifera (Grote) (Noctuidae)

\section{Drasteria occulta (Henry Edwards) (Noctuidae) \\ Erastria coloraria (Fabricius) \\ (Geometridae)}

Erynnis brizo brizo (Boisduval and Leconte) (Hesperiidae)

Erynnis martialis (Scudder) (Hesperiidae)

Erynnis persius persius (Scudder) (Hesperiidae)

\section{Eueretagrotis attenta \\ (Grote) (Noctuidae)}

\section{Eumacaria latiferrugata (Walker) (Geometridae) Glena cognataria (Guenée) (Geometridae) \\ Hemaris gracilis (Grote and Robinson) (Sphingidae)}

Hemileuca maia (Drury) (Saturniidae)

\author{
Heterocampa varia Walker \\ (Notodontidae) \\ Hypomecis buchholzaria \\ (Lemmer) (Geometridae) \\ Itame sp. 1 near inextricata ${ }^{\mathrm{a}}$ \\ (Geometridae)
}

Coastal plain shrubland habitats, including heathlands, shrubby dunes and bluffs, and acidic shrub swamps and bogs; historically more eurytopic

Pitch pine-scrub oak barrens and open oak woodlands; historically more eurytopic Rocky summits and ridges with abundant lowbush blueberry, possibly also bogs; more general and widespread northward Sandplain pitch pine-scrub oak barrens; associated with lowbush blueberry

Xeric, open habitats on sandy or rocky soil with New Jersey tea, including pitch pine-scrub oak barrens and associated sandplain communities, rocky outcrops and ridges Pitch pine-scrub oak barrens and open, oak-dominated woodlands

Pitch pine-scrub oak barrens and associated sandplain communities with New Jersey tea Xeric, open oak woodland, sandplain pitch pine-scrub oak barrens, and other disturbance-dependent habitats with wild indigo or lupine

Pitch pine-scrub oak barrens on sandplains or rocky summits and ridges (associated with lowbush blueberry); also acidic bogs and swamps with ericaceous vegetation Sandplain pitch pine-scrub oak barrens and maritime shrublands

Pitch pine-scrub oak barrens, heathlands, bogs and other wetlands with ericaceous vegetation Pitch pine-scrub oak barrens on sandplains or rocky summits and ridges (associated with lowbush blueberry); also acidic bogs and swamps with ericaceous vegetation

Xeric, open habitats with extensive scrub oak thickets, including sandplain pitch pine-scrub oak barrens, maritime shrublands, and very rarely ridgetop barrens

Xeric, open pitch pine-scrub oak barrens (e.g., the Long Island dwarf pine plains) Xeric, open habitats on sandy soil, especially sandplain pitch pine-scrub oak barrens Sandplain pitch pine-scrub oak barrens and ridgetop barrens
Polyphagous, with a preference for Gaylussacia spp., Myrica spp., and Vaccinium spp.

\section{Quercus spp.}

Undocumented, but probably Vaccinium spp.

Vaccinium spp.

Ceanothus americanus

Quercus spp., especially Q. ilicifolia

Ceanothus americanus

Baptisia tinctoria, Lupinus perennis

Vaccinium spp.

Prunus spp.; typically $P$. pensylvanica and $P$. pumila in barrens, $P$. maritima along the coast Vaccinium spp., Prunus spp., and presumably others

Vaccinium spp.

Primarily Quercus ilicifolia and Q. prinoides, very rarely $Q$. velutina; wandering late-instar larvae occasionally on other hosts

\section{Quercus ilicifolia}

Undocumented; captive larvae accept Comptonia peregrina, Myrica spp., and Quercus ilicifolia Quercus ilicifolia 
Table 1 (Continued)

\begin{tabular}{|c|c|c|}
\hline Species, authority, family & $\begin{array}{l}\text { Habitat(s) in southern New England } \\
\text { and southeastern New York }\end{array}$ & $\begin{array}{l}\text { Larval host plant(s) in southern } \\
\text { New England and southeastern New York }\end{array}$ \\
\hline $\begin{array}{l}\text { Lithophane thaxteri Grote } \\
\text { (Noctuidae) }\end{array}$ & Pitch pine-scrub oak barrens; bogs & $\begin{array}{l}\text { Comptonia peregrina; probably also many } \\
\text { Ericaceae }\end{array}$ \\
\hline $\begin{array}{l}\text { Lycaeides melissa samuelis } \\
\text { Nobokov (Lycaenidae) }\end{array}$ & $\begin{array}{l}\text { Xeric, open oak woodland, sandplain pitch } \\
\text { pine-scrub oak barrens, and other } \\
\text { disturbance-dependent habitats with lupine }\end{array}$ & Lupinus perennis \\
\hline Lycia rachelae (Hulst) (Geometridae) & Pitch pine-scrub oak barrens & Undocumented; probably polyphagous \\
\hline $\begin{array}{l}\text { Lycia ypsilon (S.A. Forbes) } \\
\quad \text { (Geometridae) }\end{array}$ & $\begin{array}{l}\text { Pitch pine-scrub oak barrens } \\
\text { (on Martha's Vineyard, Massachusetts); } \\
\text { other habitats southward }\end{array}$ & $\begin{array}{l}\text { Undocumented; polyphagous southward on } \\
\text { Clethra, Myrica, Prunus, and Quercus }\end{array}$ \\
\hline $\begin{array}{l}\text { Metarranthis apiciaria } \\
\quad \text { (Packard) (Geometridae) }\end{array}$ & $\begin{array}{l}\text { Pitch pine-scrub oak barrens } \\
\text { (on Martha's Vineyard, Massachusetts); } \\
\text { less stenotopic historically }\end{array}$ & Undocumented \\
\hline $\begin{array}{l}\text { Morrisonia mисеns (Hübner) } \\
\text { (Noctuidae) }\end{array}$ & $\begin{array}{l}\text { Sandplain pitch pine-scrub oak barrens, } \\
\text { possibly also open pine-oak woodland }\end{array}$ & Quercus spp., including $Q$. ilicifolia \\
\hline $\begin{array}{l}\text { Phoberia orthosioides }\left(\text { Guenée) }{ }^{\mathrm{b}}\right. \\
\text { (Noctuidae) }\end{array}$ & $\begin{array}{l}\text { Sandplain pitch pine-scrub oak barrens, } \\
\text { possibly also open pine-oak woodland }\end{array}$ & Quercus spp., including $Q$. ilicifolia \\
\hline $\begin{array}{l}\text { Psectraglaea carnosa } \\
\text { (Grote) (Noctuidae) }\end{array}$ & $\begin{array}{l}\text { Sandplain pitch pine-scrub oak barrens and } \\
\text { heathlands; possibly also ridgetop barrens and } \\
\text { bogs; associated with ericaceous vegetation }\end{array}$ & $\begin{array}{l}\text { Undocumented; captive larvae accept } \\
\text { Vaccinium spp. and Quercus ilicifolia }\end{array}$ \\
\hline $\begin{array}{l}\text { Satyrium edwardsii (Grote and } \\
\text { Robinson) (Lyacenidae) }\end{array}$ & $\begin{array}{l}\text { Scrub oak barrens, especially on rocky summits } \\
\text { and ridges; occasionally sandplain barrens and } \\
\text { dry woodland with scrub oak openings }\end{array}$ & Quercus ilicifolia \\
\hline $\begin{array}{l}\text { Schizura apicalis (Walker) } \\
\text { (Notodontidae) }\end{array}$ & Sandplain shrublands & $\begin{array}{l}\text { Undocumented; Ericaceae, Myricaceae, } \\
\text { Rosaceae, and Salicaceae reported elsewhere }\end{array}$ \\
\hline $\begin{array}{l}\text { Sideridis maryx (Guenée) } \\
\quad \text { (Noctuidae) }\end{array}$ & $\begin{array}{l}\text { Pitch pine-scrub oak barrens on sandplains or } \\
\text { rocky summits and ridges (associated with } \\
\text { lowbush blueberry); also acidic bogs and } \\
\text { swamps with ericaceous vegetation }\end{array}$ & Undocumented, but probably Vaccinium spp. \\
\hline Sphinx gordius Cramer $^{\mathrm{c}}$ (Sphingidae) & $\begin{array}{l}\text { Pitch pine-scrub oak barrens, heathlands, } \\
\text { and maritime shrublands; rarely bogs }\end{array}$ & $\begin{array}{l}\text { Undocumented; captive larvae accept } \\
\text { Ericaceae and Myricaceae }\end{array}$ \\
\hline $\begin{array}{l}\text { Stigmella sp., undescribed } \\
\text { (Nepticulidae) }\end{array}$ & $\begin{array}{l}\text { Xeric, open habitats on sandy or rocky soil } \\
\text { with New Jersey tea, including pitch pine-scrub } \\
\text { oak barrens and associated sandplain } \\
\text { communities, rocky outcrops and ridges }\end{array}$ & Ceanothus americanus \\
\hline $\begin{array}{l}\text { Syngrapha epigaea (Grote) } \\
\quad \text { (Noctuidae) }\end{array}$ & Pitch pine-scrub oak barrens & Vaccinium spp. \\
\hline Xylena cineritia (Grote) (Noctuidae) & $\begin{array}{l}\text { Pitch pine-scrub oak barrens and heathlands } \\
\text { on sandplains or rocky ridges and } \\
\text { summits; occasionally other shrublands }\end{array}$ & $\begin{array}{l}\text { Quercus ilicifolia and Spiraea latifolia; probably } \\
\text { Vaccinium spp. and others (presumably } \\
\text { polyphagous) }\end{array}$ \\
\hline $\begin{array}{l}\text { Xylena thoracica } \\
\quad \text { (Putnam-Cramer) (Noctuidae) }\end{array}$ & Pitch pine-scrub oak barrens; bogs northward & $\begin{array}{l}\text { Undocumented, but probably polyphagous; } \\
\text { captive larvae prefer Vaccinium spp. and } \\
\text { Prunus spp. }\end{array}$ \\
\hline Xylotype capax (Grote) (Noctuidae) & $\begin{array}{l}\text { Pitch pine-scrub oak barrens and heathlands } \\
\text { on sandplains or rocky summits and ridges }\end{array}$ & $\begin{array}{l}\text { Undocumented, but probably polyphagous; } \\
\text { Quercus ilicifolia and Vaccinium spp. are likely }\end{array}$ \\
\hline Zale sp. 1 near lunifera (Noctuidae) & $\begin{array}{l}\text { Sandplain pitch pine-scrub oak barrens, } \\
\text { especially in scrub oak thickets }\end{array}$ & Quercus ilicifolia \\
\hline $\begin{array}{l}\text { Zanclognatha martha Barnes } \\
\text { (Noctuidae) }\end{array}$ & $\begin{array}{l}\text { Inland pitch pine-scrub oak barrens, especially } \\
\text { late-successional barrens }\end{array}$ & $\begin{array}{l}\text { Undocumented, but probably plant } \\
\text { detritus; captive larvae accept dead leaves } \\
\text { of Prunus and Quercus }\end{array}$ \\
\hline
\end{tabular}

\footnotetext{
${ }^{a}$ This species is described under the incorrect combination Itame inceptaria by Forbes (1948).

${ }^{\mathrm{b}}$ Sensu Ferguson (1975); not a synonym of Phoberia atomaris.

${ }^{\mathrm{c}}$ This shrubland species is often confused with the more common Sphinx poecila, which is a different species (Riotte, 1980).
} 

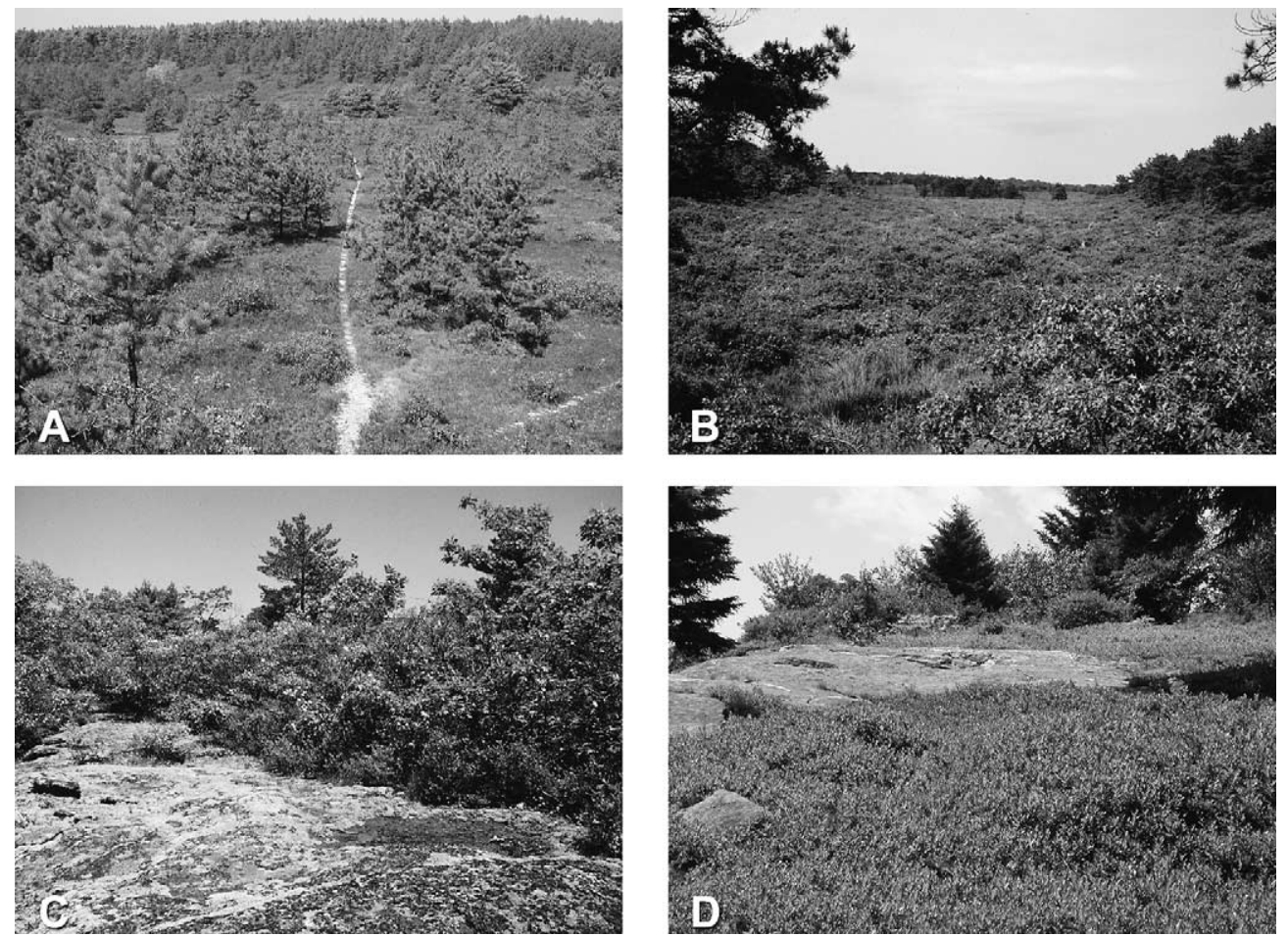

Fig. 1. Four examples of shrubland communities important for rare Lepidoptera: (A) sandplain pitch pine-scrub oak barrens (Myles Standish State Forest, Plymouth, MA); (B) scrub oak shrubland in a frost pocket (Martha's Vineyard, Massachusetts); (C) ridgetop scrub oak barrens (summit of Canaan Mountain, Canaan, CT); (D) ridgetop heath (Mount Greylock, New Ashford, MA).

southeastern New York can be considered species of sandplain and ridgetop pitch pine-scrub oak barrens (Schweitzer and Rawinski, 1987). Common and widespread species of Lepidoptera that routinely occur in shrublands but also occur in other habitats (e.g., oak forests) are not discussed.

Our treatment of shrubland Lepidoptera is admittedly somewhat arbitrary, because shrublands grade into many other natural community types. Some Lepidoptera that feed on lupine (Lupinus perennis), wild indigo (Baptisia tinctoria), or other herbaceous plants also occur in sandplain grassland communities, such as the frosted elfin (Callophrys irus (Godart)), Persius duskywing (Erynnis persius persius (Scudder)), and Karner blue (Lycaeides melissa samuelis Nobokov). These species are included because they often occur in small-scale openings within pitch pinescrub oak barrens communities. It should be noted that our discussion excludes moths that primarily occur in wetlands within a barrens landscape (e.g., Datana major Grote and Robinson and Metarranthis pilosaria (Packard)). Furthermore, habitat and host plant associations described in Tables 1 and 3 apply only to southern New England and southeastern New York because some species (typically those at the northern limit of their range) are both restricted to pitch pinescrub oak barrens and monophagous in this region, yet occur in oak and pine forests and are oligophagous or polyphagous to the south and west. For instance, the buck moth (Hemileuca maia (Drury)) occurs only in pitch pine-scrub oak barrens and oviposits almost exclusively on scrub oak in southern New England and southeastern New York; southward it inhabits forests and feeds on a variety of oaks.

There are several reasons why our taxonomic focus is restricted to the Lepidoptera. Moths, and especially butterflies, are among the best-studied terrestrial invertebrates. The species-level taxonomy of butterflies and larger moths (macro-Lepidoptera) is well established and relatively stable. The Lepidoptera is 
one of the few invertebrate groups for which there are substantial historic records for New England and New York because collectors have been active in this region for >140 years (Klots, 1951; Wagner, 2004). Also, entomologists have a greater knowledge of the requirements of the immature stages of Lepidoptera than almost any other insect group. Lastly, the Lepidoptera are an enormous data source. For instance, in the state of Connecticut alone, 2300 species of moths and butterflies have been recorded (Wagner, unpublished data).

\section{Methods}

\subsection{Sources of information on tabulated species}

The habitat and larval host plant data in Tables 1 and 3 are comprised of new information based on the authors' observations, as well as information compiled from Covell (1984), Forbes (1923, 1948, 1954, 1960), Goldstein (1997) and Handfield (1999), the Massachusetts Natural Heritage and Endangered Species Program (Division of Fisheries and Wildlife, Westborough, MA), Tim McCabe of the New York State Museum (personal communication), NatureServe (2003), Tietz (1972) and Wagner et al. (2001).

\subsection{Global and state conservation ranking system}

For the conservation status of most species we used NatureServe (2003), an independent, international provider of biodiversity information based in Arlington, VA. NatureServe maintains a computerized database that summarizes the conservation status of species based on a ranking system developed by The Nature Conservancy. Global ranks ("G ranks"), which apply range-wide, are assigned by NatureServe based on assessments by experts on particular taxonomic groups. State ranks ("S ranks") are assigned by state Heritage Program biologists, usually in consultation with local and regional authorities.

The conservation status rank of a species is designated by a number from 1 to 5 , preceded by a $G$ (global) or S (state), as appropriate. The numbers have the following meaning: $1=$ critically imperiled; $2=$ imperiled; $3=$ uncommon to rare and vulnerable to imperilment; $4=$ apparently secure; $5=$ demonstrably secure (both widespread and abundant). For example, G1 indicates critical imperilment on a range-wide basis (usually five or fewer extant occurrences); similarly, S1 indicates critical imperilment within a particular state. "Range ranks", for example, G2G3 or S3S4, denote uncertainty in the assigned rank. Species known only from historic records (generally, records more than 20 years old) are ranked $\mathrm{H}$ (historic) or X (presumed extirpated). Species of unknown conservation status are ranked U. Conservation status ranks take into account the following factors, when applicable: estimated total number and condition of populations, size of populations, extent of geographic range, trends in populations and geographic range, threats, and species traits related to vulnerability (NatureServe, 2003). Global and state conservation status ranks (Tables 2 and 4) were current as of January 2003. In cases where we believe the NatureServe state ranks to be outdated or inaccurate, we offer suggested ranks in brackets.

\section{Results and discussion}

\subsection{The importance of shrublands}

Shrublands are the most important natural communities for rare and endangered Lepidoptera in both Connecticut and Massachusetts (Fig. 2). This is especially evident in the state of Massachusetts, where $41 \%$ of state-listed moths and butterflies are associated with shrublands. In the state of Connecticut, species of shrub-dominated habitats account for $23 \%$ of the state's listed Lepidoptera. In both states, pitch pinescrub oak barrens, ridgetop pitch pine-scrub oak barrens, and heathlands are the most important shrubland habitats for rare moths and butterflies. Shrubland species also account for high percentages of Lepidoptera ranked as rare in other northeastern states. Tables 1 and 2 list 56 rare species of Lepidoptera that are associated with shrubland habitats in our study region. These species represent six families of larger moths (macro-Lepidoptera), three families of smaller moths (micro-Lepidoptera), and two families of butterflies.

The importance of pitch pine-scrub oak barrens for rare Lepidoptera is likely due to a variety of abiotic and biotic factors. However, the most obvious reason for this importance is that scrub oak is the sole or principal larval host for $16(29 \%)$ of the 56 rare 
Table 2

Rare shrubland Lepidoptera and their global and state conservation status ranks (see Table 1 for generic names) ${ }^{\mathrm{a}}$

\begin{tabular}{|c|c|c|}
\hline Species & $\begin{array}{l}\text { Global conservation } \\
\text { status rank } \\
\text { [suggested rank] }\end{array}$ & State conservation status ranks ${ }^{\mathrm{b}}$ [suggested ranks] \\
\hline Abagrotis brunneipennis & G4 & Connecticut [S1?], Maine [S4], Massachusetts [S2S4], New Hampshire [S4], New York [S4] \\
\hline Acronicta albarufa & G3G4 & Connecticut (SH), Massachusetts (S1S2) [S2S3], New York (SH) \\
\hline Acronicta lanceolaria & G4 & $\begin{array}{l}\text { Connecticut (SH), Maine (S4), Massachusetts (S4?) [SU], New Hampshire (S3), } \\
\text { Rhode Island (SU), New York [S4] }\end{array}$ \\
\hline Anacampsis lupinella & [GU] & Connecticut [S1], New Hampshire [S1], New York [S2S3] \\
\hline Anisota stigma & G5 & Connecticut (SH), Massachusetts (S2S3) [S3], New Hampshire (SH), New York (SU) \\
\hline Apharetra dentata & G4 & $\begin{array}{l}\text { Connecticut [S1], Maine (S3), Massachusetts (S2S3) [S3S4], New Hampshire (S2), } \\
\text { New York (S2S3), Rhode Island (S1S2) }\end{array}$ \\
\hline Apodrepanulatrix liberaria & G4 & Connecticut (S1S2) [S1], Massachusetts (S2S3) [S1S2], New Hampshire (S1S2) [S1] \\
\hline Callophrys irus & G3 & $\begin{array}{l}\text { Connecticut (S1S3) [S2S3], Maine (SX), Massachusetts (S2S3), New Hampshire (S1), } \\
\text { New York (S1S3), Rhode Island (S1) }\end{array}$ \\
\hline Callophrys polios & G5 & $\begin{array}{l}\text { Connecticut (SH), Maine (S4), Massachusetts (S4) [S3], New Hampshire (SH), } \\
\text { New York (S4) [S1S2], Rhode Island (S1) }\end{array}$ \\
\hline Cameraria castaneaeella & [GU] & Connecticut [SU] \\
\hline Catocala badia & G4 & Connecticut [S3], Massachusetts [S4], New York (S2S4), Rhode Island [S4] \\
\hline Catocala herodias gerhardi & G3 & Connecticut (S1), Massachusetts (S2S3) [S3], New York (S2S3) \\
\hline Catocala jair ssp. 2 & G4 & New York (S1S2) \\
\hline Catocala muliercula & G5 & Connecticut (S1) [S1S3], Massachusetts (S1?) [S2S4], New York (SU), Rhode Island [SU] \\
\hline Catocala sp. 1 near jair & G5 & $\begin{array}{l}\text { Connecticut (SU), Massachusetts (S3), New Hampshire (S1S2), New York [S1S3], } \\
\text { Rhode Island (S1S3) }\end{array}$ \\
\hline Catocala sp. 3 near ilia & G4G5 & Massachusetts [SU], New York (SH) \\
\hline Cerma cora & G3G4 & Maine [SH], Massachusetts (SH) [SX], New Hampshire (S1S2), New York (S1S3) \\
\hline Chaetaglaea cerata & G3G4 & $\begin{array}{l}\text { Connecticut (SH) [S1S2], Maine (SH), Massachusetts (S3) [S2S3], New Hampshire } \\
\text { (S1S2), New York (S1S2) }\end{array}$ \\
\hline Chaetaglaea tremula & G5 & $\begin{array}{l}\text { Connecticut (S3) [S2S3], Maine (S2S3), Massachusetts (S4S5) [S4], New York (S4), } \\
\text { Rhode Island (S4) }\end{array}$ \\
\hline Chytonix sensilis & G4 & $\begin{array}{l}\text { Connecticut (SU) [SH], Maine [SH], Massachusetts (S1S3), New Hampshire (S1S2), } \\
\text { New York (S1S3) }\end{array}$ \\
\hline Cicinnus melsheimeri & G4 & Connecticut [SX], Massachusetts (S1S3) [S2S3], New York (SH) \\
\hline Cingilia catenaria & G4 & $\begin{array}{l}\text { Connecticut (SH) [S1], Maine [S4?], Massachusetts (S2S4) [S2S3], New Hampshire (S4), } \\
\text { New York [SU] }\end{array}$ \\
\hline Datana contracta & G5 & Connecticut [SU], Massachusetts [SU], New York [SU] \\
\hline Diarsia rubifera & G5 & Connecticut [SU], Maine [S4S5], Massachusetts [SU], New York [S4], Rhode Island (SU) \\
\hline Drasteria occulta & G4 & $\begin{array}{l}\text { Connecticut [SH], Maine [S4], Massachusetts [S3S4], New Hampshire [SU], } \\
\text { New York [SU] }\end{array}$ \\
\hline Erastria coloraria & G4 & Connecticut (SH) [SX], Massachusetts [SH], New Hampshire (S1) [SX], New York (S2S3) \\
\hline Erynnis brizo brizo & G5 & $\begin{array}{l}\text { Connecticut (S3) [S2], Maine (S2), Massachusetts (S4), New Hampshire (S2), } \\
\text { New York (S4) }\end{array}$ \\
\hline Erynnis martialis & G3G4 & $\begin{array}{l}\text { Connecticut (SH) }[\mathrm{SX}] \text {, Massachusetts (SX), New Hampshire (SX), New York (S1S2), } \\
\text { Rhode Island (SH) }\end{array}$ \\
\hline Erynnis persius persius & G2G3 & $\begin{array}{l}\text { Connecticut (S1), Maine (SX), Massachusetts (S1S3) [S1], New Hampshire (S1), } \\
\text { New York (SH), Rhode Island (SH) }\end{array}$ \\
\hline Eueretagrotis attenta & G4 & Connecticut [S1], Maine [S5], Massachusetts [SU], New York [S4] \\
\hline Eumacaria latiferrugata & G4 & Maine (S4), Massachusetts (S4?) [S3S4], New Hampshire (S2S4), New York (S2S4) \\
\hline Glena cognataria & G4 & $\begin{array}{l}\text { Connecticut (SH), Maine (S4), Massachusetts (S3?) [S3], New Hampshire (S3?), } \\
\text { New York (S1S3) }\end{array}$ \\
\hline Hemaris gracilis & G3G4 & $\begin{array}{l}\text { Connecticut (S1), Maine (SH), Massachusetts (SU) [S2S3], New Hampshire (S2S3), } \\
\text { New York (SU) }\end{array}$ \\
\hline Hemileuca maia & G5 & $\begin{array}{l}\text { Connecticut (S1), Maine (S1), Massachusetts (S2S3) [S3], New Hampshire (SH), } \\
\text { New York (S2), Rhode Island (S1S2) }\end{array}$ \\
\hline Heterocampa varia & G3G4 & New York (S1S2) \\
\hline Hypomecis buchholzaria & G3G4 & Massachusetts (S1), New York (SH) \\
\hline
\end{tabular}


Table 2 (Continued)

\begin{tabular}{|c|c|c|}
\hline Species & $\begin{array}{l}\text { Global conservation } \\
\text { status rank }^{\mathrm{b}} \\
\text { [suggested rank] }\end{array}$ & State conservation status ranks ${ }^{\mathrm{b}}$ [suggested ranks] \\
\hline Itame sp. 1 near inextricata & G3 & $\begin{array}{l}\text { Connecticut [S1], Maine (S1), Massachusetts (S2S3), New Hampshire (S1S2), } \\
\text { New York (S1) }\end{array}$ \\
\hline Lithophane thaxteri & G4 & $\begin{array}{l}\text { Connecticut (SH), Maine (S4), Massachusetts (S2S3), New Hampshire (SU), } \\
\text { New York (SU), Rhode Island (SU) }\end{array}$ \\
\hline Lycaeides melissa samuelis & G2 & Maine (SX), Massachusetts (SX), New Hampshire (S1) [SX], New York (S1) \\
\hline Lycia rachelae & G4 & Maine (S1), Massachusetts (SH) [S1], New Hampshire (S2) \\
\hline Lycia ypsilon & G4 & Massachusetts (S?) [S1], New York (SH) \\
\hline Metarranthis apiciaria & GU & $\begin{array}{l}\text { Connecticut (SH), Maine (SU), Massachusetts (S1S2) [S1], New Hampshire (S1), } \\
\text { New York (SH) }\end{array}$ \\
\hline Morrisonia mucens & G4G5 & Massachusetts (S1S3), New York (S1S3) \\
\hline Phoberia orthosioides & G4 & Massachusetts [SU], New York (S2S3) \\
\hline Psectraglaea carnosa & G3 & $\begin{array}{l}\text { Connecticut (S1), Maine (SH), Massachusetts (S3) [S2S3], New Hampshire (SH), } \\
\text { New York (S2) }\end{array}$ \\
\hline Satyrium edwardsii & G4 & $\begin{array}{l}\text { Connecticut (S4) [S3], Maine (S1), Massachusetts (S4), New Hampshire (S3), } \\
\text { New York (S3S4), Rhode Island (S5) [S4] }\end{array}$ \\
\hline Schizura apicalis & G2G4 & Massachusetts (S3S4) [S1S2], New York (SU), Rhode Island (S2S3) [S1?] \\
\hline Sideridis maryx & G4 & Connecticut [S2], Maine [S4], Massachusetts [S2S4], New York (S2S3) \\
\hline Sphinx gordius & G4 & Massachusetts [S2S4], New York (S1S3), Rhode Island [S1?] \\
\hline Stigmella sp., undescribed & {$[\mathrm{GU}]$} & Connecticut $[\mathrm{S} 2 \mathrm{~S} 4]$ \\
\hline Syngrapha epigaea & G5 & Maine [S4], New Hampshire [S4], New York [S4] \\
\hline Xylena cineritia & G4 & $\begin{array}{l}\text { Connecticut [S2S4], Maine [S4], Massachusetts [S2S4], New Hampshire [S3S4], } \\
\text { New York [S4] }\end{array}$ \\
\hline Xylena thoracica & G4 & Maine (S3), New Hampshire (S2), New York (S1S2) \\
\hline Xylotype capax & G4 & $\begin{array}{l}\text { Connecticut (SU), Maine (S3) [S2S3], Massachusetts (S4), New Hampshire (S2), } \\
\text { New York (S3S4), Rhode Island (S2S4) }\end{array}$ \\
\hline Zale sp. 1 near lunifera & G3G4 & $\begin{array}{l}\text { Connecticut (SU), Maine (S1), Massachusetts (S2S3), New Hampshire (S1), } \\
\text { New York (SU), Rhode Island (S1) }\end{array}$ \\
\hline Zanclognatha martha & G4 & $\begin{array}{l}\text { Connecticut [S2], Maine (S1), Massachusetts (S1) [S2], New Hampshire (S1), } \\
\text { New York (S1S2), Vermont (S1?) }\end{array}$ \\
\hline
\end{tabular}

${ }^{\mathrm{a}}$ For rank definitions, please refer to Section 2.1.

${ }^{\mathrm{b}}$ NatureServe (2003). Most of the NatureServe global conservation status ranks and many of the state ranks were assigned by Schweitzer; the authors' suggested updates appear in brackets.

shrubland species (Fig. 3). Next in relative importance are lowbush blueberries (Vaccinium angustifolium and V. pallidum), the sole or primary hosts in southern New England and southeastern New York for eight (14\%) of the 56 species. Moreover, the importance of scrub oak and lowbush blueberries is underrepresented in Fig. 3, as many of the 12 polyphagous species utilize one or both of these hosts. Interestingly, only seven plant genera support $65 \%$ of the host-specialized shrubland Lepidoptera in Table 1. If polyphagous species are considered, $86 \%$ of the 56 rare shrubland species are supported by the seven plant genera (Fig. 3).

Uncommon to rare Lepidoptera that feed on pitch pine in barrens of southern New England and southeastern New York are listed in Tables 3 and 4.
These species were excluded from our main discussion because pitch pine is a tree (not a shrub), most of them feed on other hard pines elsewhere, and they may inhabit closed-canopy forests and pine plantations. Nevertheless, it is important to note that within our region, the species in Tables 3 and 4 are either restricted to or reach their greatest abundance in pitch pine-scrub oak barrens, and would likely be lost without efforts to conserve and manage the region's shrubland communities.

Besides Lepidoptera, many other phytophagous insects undoubtedly have similar levels of specialization and dependency on shrub-dominated communities. Examples include the thrips (Thysanoptera), true bugs and homopterans (Hemiptera), longhorn and 


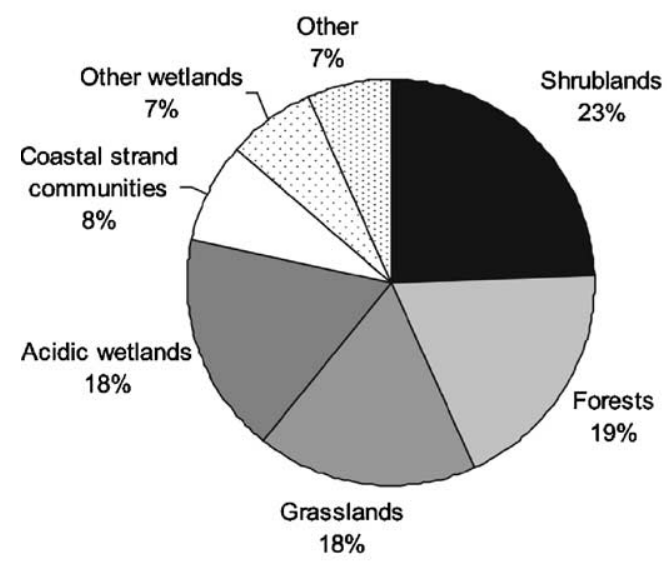

Connecticut

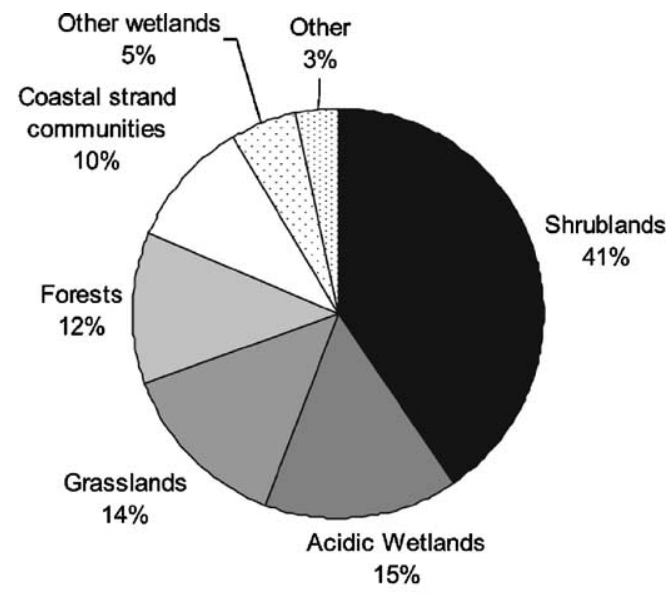

Massachusetts

Fig. 2. Proportion of state-listed Lepidoptera that are shrubland species in Connecticut (CT DEP, 1998) and Massachusetts (MA DFW, 2003). Historic species are retained in the Connecticut list, but excluded from the Massachusetts list.

leaf beetles (Chrysomeloidea), weevils (Curculionoidea), and sawflies (Symphyta). Coprophagous scarab beetles (e.g., Geotrupes spp. and Copris spp., Scarabaeidae), along with many phytophagous scarabs, peak in species richness in sandplain shrubland communities on the offshore islands of Massachusetts; both abundance of individual scarab species and the number of rare species present are highest in

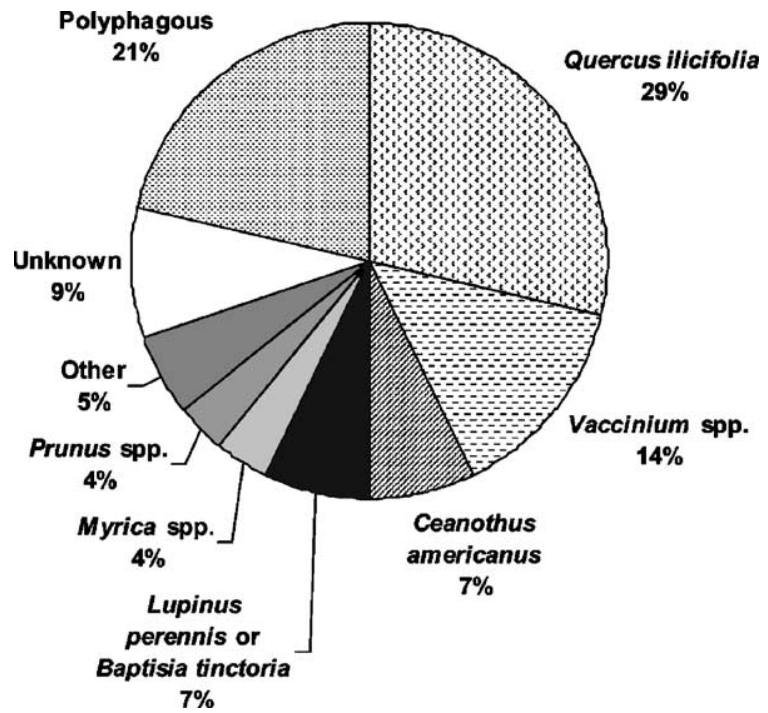

Fig. 3. Host plant associations of rare shrubland Lepidoptera in southern New England and southeastern New York. shrublands, as opposed to grasslands and other sandplain communities (Goldstein and Simmons, 2002). Moreover, there are parasitic wasps (Hymenoptera) and tachinid flies (Diptera) that specialize on the phytophagous insects restricted to shrubland communities.

In addition, there are unique predators and scavengers found in shrublands. Robber flies (Asilidae) associated with pitch pine-scrub oak barrens include Cyrtopogon lutatius (Walker), Laphria cinerea (Back), L. virginica (Banks), and Proctacanthus rufus Williston (Bromley, 1946; Michael Thomas, personal communication). The absence of any of these four asilids is an indication of degraded barrens habitat (McCabe and Weber, 1994). Other generalist predators rely on the edaphic or other unusual environmental conditions of shrublands, rather than the presence of particular plant or prey species. The barrens tiger beetle (Cicindela patruela DeJean), a species of barrens and open woodlands range-wide (Boyd, 1978; Knisley and Schultz, 1997; US Fish and Wildlife Service, 2001), is only known in New England from the pitch pine-scrub oak barrens of Plymouth, Massachusetts. The owl fly Ulolodes quadrimacuatus Say is closely tied to barrens and other sandplain habitats in the Northeast. Another example is the ant Leptothorax davisi Wheeler, which is known only from the pitch pine-scrub oak barrens of southern New Jersey, Long Island, New York, and Martha's 
Table 3

Rare pitch pine-feeding Lepidoptera and their habitat and host plant associations in southern New England and southeastern New York

\begin{tabular}{|c|c|c|}
\hline Species, authority, family & $\begin{array}{l}\text { Habitat(s) in southern New England } \\
\text { and southeastern New York }\end{array}$ & $\begin{array}{l}\text { Larval host plant(s) in southern } \\
\text { New England and southeastern New York }\end{array}$ \\
\hline $\begin{array}{l}\text { Citheronia sepulcralis Grote and } \\
\text { Robinson (Saturniidae) }\end{array}$ & Pitch pine-scrub oak barrens, pine forests & Pinus rigida, occasionally other Pinus spp. \\
\hline Corticivora clarki Clarke (Tortricidae) & Pitch pine-scrub oak barrens & Pinus rigida \\
\hline Corticivora parva Brown (Tortricidae) & Pitch pine-scrub oak barrens & Pinus rigida \\
\hline Dasychira pinicola (Dyar) (Lymantriidae) & Pitch pine-scrub oak barrens, pine forests & Pinus rigida \\
\hline Decantha stecia Hodges (Oecophoridae) & Pitch pine-scrub oak barrens & $\begin{array}{l}\text { Undocumented; larvae probably feed } \\
\text { under bark of Pinus rigida }\end{array}$ \\
\hline Hilarographa jonesi Brower (Tortricidae) & Pitch pine-scrub oak barrens & $\begin{array}{l}\text { Undocumented; larvae probably feed in } \\
\text { bark of Pinus rigida }\end{array}$ \\
\hline $\begin{array}{l}\text { Lapara coniferarum (J.E. Smith) } \\
\text { (Sphingidae) }\end{array}$ & $\begin{array}{l}\text { Pitch pine-scrub oak barrens, } \\
\text { occasionally pitch pine forest }\end{array}$ & Pinus rigida \\
\hline Lithophane lepida lepida Grote (Noctuidae) & Pitch pine-scrub oak barrens, pitch pine forest & Pinus rigida \\
\hline Zale curema (Small) (Noctuidae) & Pitch pine-scrub oak barrens, pitch pine forest & Pinus rigida \\
\hline Zale squamularis (Drury) (Noctuidae) & Pitch pine-scrub oak barrens & Pinus rigida \\
\hline Zale submediana Strand (Noctuidae) & Pitch pine-scrub oak barrens, pitch pine forest & Pinus rigida \\
\hline
\end{tabular}

Vineyard, Massachusetts (Creighton, 1950; Stefan Cover, personal communication).

\subsection{The unique environment of pitch pine-scrub oak barrens and other shrublands}

In southern New England and southeastern New York, pitch pine-scrub oak barrens occur on glacial outwash deposits characterized by acidic, sandy soils (Motzkin et al., 1999, 2002b; Foster et al., 2002; Parshall and Foster, 2002), or on rocky summits and ridges of acidic bedrock (Motzkin et al., 2002c). Such soils hold little water and periods of drought are common, especially during late summer and early autumn. At a regional scale, sandplain barrens are among the most xeric natural communities in the Northeast, and

Table 4

Rare pitch pine-feeding Lepidoptera and their global and state conservation status ranks ${ }^{\mathrm{a}}$

\begin{tabular}{|c|c|c|}
\hline Species & $\begin{array}{l}\text { Global conservation status } \\
\text { rank }^{\mathrm{b}} \text { [suggested rank] }\end{array}$ & $\begin{array}{l}\text { State conservation status } \\
\text { ranks }^{\mathrm{b}} \text { [suggested ranks] }\end{array}$ \\
\hline Citheronia sepulcralis & G5 & $\begin{array}{l}\text { Maine (SH), Massachusetts (SX), New Hampshire (SX), } \\
\text { New York (S1) [SH], Rhode Island (SX) }\end{array}$ \\
\hline Corticivora clarki & {$[\mathrm{GU}]$} & Massachusetts [SU] \\
\hline Corticivora parva & {$[\mathrm{GU}]$} & Massachusetts [SU] \\
\hline Dasychira pinicola & G4 & Massachusetts [S4], New York (SU) \\
\hline Decantha stecia & {$[\mathrm{GU}]$} & Connecticut [SU], Massachusetts [SU] \\
\hline Hilarographa jonesi & {$[\mathrm{GU}]$} & Connecticut [S1S3], Massachusetts [SU] \\
\hline Lapara coniferarum & G5 & $\begin{array}{l}\text { Connecticut [SU], Maine (S2S3), Massachusetts [S4], } \\
\text { New Hampshire (S1S2), New York (S4), Rhode Island [SU] }\end{array}$ \\
\hline Lithophane lepida lepida & G3G4 & Maine (SU), New Hampshire (S1S2), New York (S1) \\
\hline Zale curema & G3G4 & $\begin{array}{l}\text { Connecticut (S1), Massachusetts (S4), New Hampshire (S2), } \\
\text { New York (SU) }\end{array}$ \\
\hline Zale squamularis & G4 & New York (S3S4) \\
\hline Zale submediana & G4 & $\begin{array}{l}\text { Connecticut (S1), Maine [S4?], Massachusetts [S4], New Hampshire } \\
\text { (S3), New York [S4?], Rhode Island (S2), Vermont (S1?) }\end{array}$ \\
\hline
\end{tabular}

\footnotetext{
${ }^{\text {a }}$ For rank definitions, please refer to Section 2.1.

${ }^{\mathrm{b}}$ NatureServe (2003). Most of the NatureServe global conservation status ranks and many of the state ranks were assigned by Schweitzer; the authors' suggested updates appear in brackets.
} 
may be thought of as "northeastern deserts". In part because of the extreme edaphic conditions, canopy cover, plant biomass, and leaf litter tend to be sparse relative to nearby oak woodlands (Motzkin et al., 2002a).

Within barrens, patches of exposed sand or rock are home to many ground-dwelling invertebrates that have phylogenetic affinity to taxa reaching greatest diversity in deserts and similar xeric ecosystems. Loose, sandy soil is ideal for burrowing and dries and warms readily, benefiting southern species near the northern limit of their geographic range (Kirby, 2001). Arthropod groups with species dependent on sandy substrates or open patches of bare ground for nesting or foraging include the ant-lions (Myrmelionidae), ground beetles (Carabidae), scarab beetles (Scarabaeidae), bee flies (Bombyliidae), robber flies (Asilidae), ants (Formicidae), bees (Apoidea), sand wasps (Sphecidae), and velvet wasps (Mutillidae). There are numerous spiders (Araneae) and spider wasps (Pompilidae) that also need open ground in pitch pine-scrub oak barrens and other shrubland habitats.

The reduced canopy cover of shrublands in general, and pitch pine-scrub oak barrens in particular, results in a great amount of solar radiation reaching ground level, where daytime temperatures may reach $>40{ }^{\circ} \mathrm{C}$ during the summer (Motzkin et al., 2002a). Such elevated temperatures may be necessary for successful development of lepidopteran larvae near the northern limit of their range, e.g., the spiny oakworm (Anisota stigma (Fabricius)) and Melsheimer's sack-bearer (Cicinnus melsheimeri (Harris)). In contrast, the flat topography, reduced canopy cover, and dry soil of shrublands result in rapid radiational cooling at night (Motzkin et al., 2002a). An especially dramatic example is provided by frost pockets (or "frost bottoms"), which are kettleholes and valleys in glacial outwash plains into which cold night air drains and is trapped. In Myles Standish State Forest in Massachusetts, Aizen and Patterson (1995) showed that during the growing season on calm, clear nights, frost pocket temperatures may average more than $6{ }^{\circ} \mathrm{C}$ cooler than adjacent uplands just tens of meters away. Consequently, frost pockets often experience late freezes in the spring and early frosts in the fall (Schweitzer and Rawinski, 1987; Foster and Motzkin, 1999; Motzkin et al., 2002a). One of the consequences of the exceptional microclimate of frost pockets is delayed spring leaf-out relative to nearby forested areas. In the frost pockets studied by Aizen and Patterson (1995), scrub oak leafed out 2-3 weeks later than oaks in adjacent uplands.

Frost pockets found in pitch pine-scrub oak barrens are important habitat for many regionally rare and endangered Lepidoptera (Goldstein, 1997). Many of the species listed in Table 1 occur in frost pockets on Martha's Vineyard, Massachusetts (Goldstein, 1992a,b, 1994). Species such as Gerhard's underwing (Catocala herodias gerhardi Barnes and Benjamin) and the buck moth are thought to reach their greatest regional population densities in frost pockets. The importance of frost pockets to regionally rare Lepidoptera that feed on oaks in spring may be the result of delayed leaf phenology. Young, tender leaves are more nutritious than older leaves because of their greater nitrogen and water content (Feeney, 1970; Slansky, 1993). Buck moth larvae reared on young foliage develop more rapidly and achieve greater pupal weight than larvae reared on older leaves (Foil et al., 1991). The delayed spring leaf-out in frost pockets provides highly nutritious food concurrent with sufficiently warm and sunny days (for larval basking) to allow a more rapid rate of digestion and growth, thus shortening the duration larvae are exposed to predators and parasitoids. Accelerated digestion and growth also allows a greater amount of tissue assimilation during the larval period, resulting in more massive pupae which in females may lead to greater fecundity (Awmack and Leather, 2002).

Reduced mortality from parasitoids in open shrublands as compared to forested habitats may be important for regionally rare Lepidoptera; of particular concern is the tachinid fly Compsilura concinnata Meigen (Boettner et al., 2000). C. concinnata is a generalist parasitoid introduced from Europe to control the gypsy moth (Lymantria dispar L.) and the brown-tail moth (Euproctis chrysorrhoea L.) (Webber and Schaffner, 1926). C. concinnata attacks more than 180 species of native Lepidoptera (Schaffner and Griswold, 1934; Schaffner, 1959; Arnaud, 1978), produces three to four generations per year, and can reach very high local densities (Williams et al., 1992; Boettner, personal communication). In a field experiment carried out by Boettner et al. (2000), not one of the 500 cecropia moth caterpillars (Hyalophora cecropia L.) released in central Massachusetts 
survived to pupation; $C$. concinnata accounted for $81 \%$ mortality. Boettner et al. (2000) suggest that the promethea moth (Callosamia promethea (Drury)) and many Datana spp. are similarly impacted by $C$. concinnata. Furthermore, it is possible that some of the regional extirpations documented in New England (e.g., the regal moth (Citheronia regalis Grote) and the pine devil moth (Citheronia sepulcralis Grote and Robinson)), as well as regional declines of the imperial moth (Eacles imperialis (Drury)) and the wild cherry sphinx (Sphinx drupiferarum J.E. Smith), were hastened by $C$. concinnata or other introduced parasitoids. Most of the species that were extirpated or have declining populations have large larvae that mature in mid- to late-summer when large numbers of $C$. concinnata adults emerge from parasitized gypsy moth caterpillars.

In the northeastern US, pitch pine-scrub oak barrens tend to occur on sandy or rocky soils that have little agricultural value, and some barrens were never altered by human land use. For example, much of the extensive scrub oak barrens on the island of Martha's Vineyard were never cleared or plowed for agriculture (Foster and Motzkin, 1999), and the species composition and natural disturbance of these areas have remained relatively unchanged for thousands of years (Foster et al., 2002). Historically unaltered barrens are especially important habitat for regionally rare species such as Lycia ypsilon (S.A. Forbes), which in our study region occurs only in the Martha's Vineyard barrens. Similarly, one of two remaining populations of Lycia rachelae (Hulst) in Massachusetts occurs on a 350 ha barrens remnant that has also remained undisturbed by human land use (Massachusetts Natural Heritage and Endangered Species Program, unpublished data). Because adult female Lycia moths are wingless and flightless, dispersal ability is poor and their persistence in particular barrens may be more directly related to the historically unaltered nature of these sites than to the unique vegetation or environmental characteristics of the habitat.

\subsection{Habitat conservation and natural disturbance}

The greatest threat to shrubland Lepidoptera in our study region is the destruction and fragmentation of remaining native shrublands. This is especially true in the states of New York, Connecticut, Massachusetts, and New Hampshire, where pitch pine-scrub oak barrens and scrub oak shrublands have been substantially reduced compared to their historic extent. For example, $60-70 \%$ of the total area once covered by pitch pine-scrub oak barrens in Massachusetts has been lost (Barbour et al., 1998). Although no estimate is available for the state of Connecticut, the destruction is nearly complete with no large, contiguous sandplain barrens remaining. Small, remnant fragments of barrens habitat do not support many of the more specialized shrubland Lepidoptera; several studies have found a depauperate fauna at sites much less than 500-1000 ha (Cryan, 1985; Schweitzer and Rawinski, 1987; Givnish et al., 1988; Schweitzer, 1994). Based on information regarding the original extent of habitat, Schweitzer (1994) concluded that for the Karner blue, a habitat area of at least 4000 ha was necessary to support a viable metapopulation since the end of the Holocene xerothermic interval (5000 years B.P., Davis et al., 1980). Therefore, the largest remaining contiguous tracts of pitch pine-scrub oak barrens habitat should be high priorities for conservation, not only in consideration of the area-specific requirements and colonization abilities of particular species, but also because large areas of unfragmented habitat are more likely to experience natural disturbance of sufficient frequency, severity, and extent.

In northeastern North America, shrubland habitats require periodic natural disturbance to persist. Historically, fire has been a common natural disturbance in sandplain pitch pine-scrub oak barrens throughout this region (Foster and Motzkin, 1999; Motzkin et al., 1999, 2002b; Foster et al., 2002; Parshall and Foster, 2002; Lorimer and White, 2003). The historic frequency and large extent of fires in sandplain barrens can be explained in large part by the dry environment and highly flammable vegetation characteristic of such communities (Parshall and Foster, 2002). Although fire may be a common natural disturbance in ridgetop pitch pine-scrub oak barrens as well, some ridgetop barrens may persist in the absence of frequent fire because of the harsh edaphic conditions and wind and ice damage from winter storms (Motzkin et al., 2002c; Lorimer and White, 2003).

During the second half of the 20th century, modern fire detection and suppression practices have greatly limited the frequency and extent of fires in sandplain pitch pine-scrub oak barrens of southern New England 
and southeastern New York (Foster and Motzkin, 1999; Motzkin et al., 1999, 2002b; Foster et al., 2002; Lorimer and White, 2003). If fire exclusion continues in these areas, the varied age structure and species composition of the plant community will likely change (Lorimer and White, 2003). Eventually, white pine (Pinus strobus) and shade-tolerant hardwoods will replace barrens vegetation (Motzkin et al., 1999, 2002b), and important habitat will be lost. Many of the 56 rare species of Lepidoptera listed in Table 1 appear to reach greatest population densities within (or indeed, are entirely restricted to) open-canopy shrubland barrens. For example, the Karner blue is a species of open pitch pine-scrub oak barrens and oak savanna habitats maintained by fire (Cryan, 1985; Givnish et al., 1988; Haack, 1993; Schweitzer, 1994; US Fish and Wildlife Service, 2001). Although the Karner blue survives in the Albany Pine Bush, this area has lost several species to habitat destruction and fragmentation followed by fire suppression, including the Persius duskywing, slender clearwing (Hemaris gracilis (Grote and Robinson)), and pink sallow moth (Psectraglaea carnosa (Grote)) (McCabe, 1995).

\subsection{Habitat management}

Management techniques such as prescribed burning or mechanical cutting are often effective means of maintaining disturbance-dependent shrubland habitats (Christensen, 1985; McCabe, 1995; New, 1997; Barbour et al., 1998). Because fire is a natural disturbance in pitch pine-scrub oak barrens (Foster and Motzkin, 1999; Motzkin et al., 1999; Foster et al., 2002; Parshall and Foster, 2002), it is a preferred method of habitat management in barrens and other fire-adapted natural communities. In addition to maintaining open habitat structure, periodic fires release scarce nutrients, increase primary production, and stimulate flowering, germination, and seedling establishment of fireadapted shrubs and herbs (Christensen, 1985). Severe surface fires characteristic of barrens communities will often kill above-ground vegetation and consume much litter and humus (Foster and Motzkin, 1999), and may expose areas of bare soil needed by grounddwelling invertebrates (Kirby, 2001).

Effects of fire vary among insect species as a result of differences in dispersal behavior, female host selection and oviposition behavior, and larval resource requirements (Schowalter, 1985). Fire-sensitive species may be excluded from an area for several years after it has burned. Some species, such as the barrens fungus moth (Chytonix sensilis Grote), may peak in abundance more than a decade after a fire (McCabe, 1995). Because the effects of burns are different from one species to another, an optimal burn frequency probably does not exist (Christensen, 1985). Instead, the importance of population refugia for Lepidoptera and other shrubland invertebrates should be emphasized, especially for species with metapopulation dynamics (Thomas and Jones, 1993; Kirby, 2001). In other words, recolonization of burned habitat can be expected if habitat refugia of sufficient size and proximity are left unburned.

Mechanical cutting, including mowing, "brushhogging" of shrubs, or cutting of trees can be effective management tools for maintaining and restoring shrublands. For example, habitat at the Atlantic City International Airport in New Jersey has been cut regularly since the 1940s and supports populations of the barrens dagger moth (Acronicta albarufa Grote), frosted elfin, slender clearwing, and Edwards' hairstreak (Satyrium edwardsii (Grote and Robinson)). It should be noted, however, that vegetation cut annually does not support some of the scrub oak feeders such as Gerhard's underwing. As with prescribed burns, it is wise to leave portions of the habitat untreated in any sort of mechanical cutting regime.

In pitch pine-scrub oak barrens not historically altered by human land use, treatments such as plowing or harrowing are undesirable because they destroy the root stock of native vegetation. Native barrens plants, including scrub oak and a variety of ericaceous species such as lowbush blueberries, black huckleberry (Gaylussacia baccata), and especially wintergreen (Gaultheria procumbens), are slow to recolonize areas that have been plowed (Motzkin et al., 1999, 2002b; Donohue et al., 2000). In barrens recently scarified by plowing or harrowing, weedy invasive plants become more readily established at the expense of native shrubs important to rare Lepidoptera such as scrub oak and lowbush blueberries (Foster and Motzkin, 1999; authors' observations). This initial crop of weedy invasives may be replaced by a monoculture of pitch pine or white pine (Foster and Motzkin, 1999; Kirby, 2001; authors' observations). In some areas, pitch pine stands occur primarily on 
former agricultural fields, and plants characteristic of unplowed sites (scrub oak and various ericads) have not successfully recolonized formerly plowed areas during the 50-100 years since agricultural abandonment (Motzkin et al., 1999).

Degraded habitat can often be at least partially restored. In areas formerly supporting heath or scrub oak that have been converted to conifer plantations, tree cutting can lead to heath and scrub regeneration because the native seed bank may remain viable for fifty years or more (Kirby, 2001). Further recolonization by heath and scrub may occur if these plants grow nearby. Following cutting of planted conifers, controlled burning is desirable to kill young pines that typically sprout in such areas, and to stimulate rapid sprouting of native shrubs (Foster and Motzkin, 1999). It should be noted, however, that "restored" heath and barrens communities will often lack the diverse invertebrate fauna (which may have taken centuries to develop) found in communities not historically exposed to unnatural disturbance (Kirby, 2001). As such, restored habitat should not be considered an equivalent substitute for historically unaltered habitat.

A third management alternative that has not been widely investigated in northeastern North America is grazing. Grazing flocks of sheep or cattle have been part of the heathlands in England for many centuries, and are the preferred means of maintaining such cultural landscapes and their diverse and threatened invertebrate fauna (Kirby, 2001). We are not aware of any evidence that pitch pine-scrub oak barrens communities in southern New England and southeastern New York were ever extensively grazed, and the effects of grazing on the barrens flora and fauna of this region are essentially unknown. Therefore, grazing is probably an undesirable management option for scrub oak barrens, at least until the effects of such treatment have been thoroughly studied. However, coastal heathlands and grasslands such as those found on Cape Cod and the offshore islands of Massachusetts are largely the result of historic land use including grazing (Foster, 2002; Foster et al., 2002; Motzkin and Foster, 2002); therefore grazing may be a suitable management option in these habitats (Motzkin and Foster, 2002).

Regardless of the management technique used, maintenance of both the species composition and structural diversity of the plant community is necessary if preservation of the native insect community is a goal (Kirby, 2001). Considering the habitat requirements of rare Lepidoptera (Table 1) and other insects, sandplain pitch pine-scrub oak barrens in southern New England and southeastern New York should consist of a mosaic including patches of bare sand, openings dominated by lichens, grasses and heath, thickets of scrub oak, and pitch pine and oak trees in a complete range of canopy cover from isolated trees grading to a closed canopy in the forest surrounding the barrens proper. Such a complex habitat structure was probably maintained historically by fires of varied severity and extent across a varied topography. A combination of mechanical cutting followed by prescribed fire may be necessary to maintain such structure in the modern landscape (Motzkin and Foster, 2002; Motzkin et al., 1999; Kirby, 2001). In particular, a combination of cutting and fire is probably the only controlled way to obtain effects similar to severe summer fires (Tim Simmons, personal communication).

Prescribed burns and other management techniques that maintain the structure of shrubland habitat will often increase the quantity of specific resources required by Lepidoptera, i.e., larval host plants and adult nectar sources (New, 1997). A number of rare butterflies need larval hosts that grow in disturbancedependent habitats; in our study region, examples include the frosted elfin, Persius duskywing, and Karner blue, all of which feed on lupine or wild indigo; the hoary elfin (Callophrys polios (Cook and Watson)), which feeds on bearberry (Arctostaphylos uva-ursi), and the mottled skipper (Erynnis martialis (Scudder)), a specialist on New Jersey tea (Ceanothus americanus).

An often overlooked threat to shrubland Lepidoptera in the northeastern US is overgrazing of larval host plants by dense populations of white-tailed deer (Odocoileus virginianus) (McCabe, 1995). Overgrazing by deer may have contributed to the decline of lupine in the Albany Pine Bush between 1975 and 1987, destroying an entire deme of the Karner blue. Schweitzer (personal observations) suspects overgrazing by deer as the cause of the recent extirpation of the frosted elfin and the mottled skipper at two serpentine barrens in the state of Pennsylvania. In a small, remnant barrens habitat in Connecticut, Wagner (unpublished data) observed New Jersey tea grazed nearly to ground level; because this plant is the 
sole larval host for several species of rare shrubland Lepidoptera (Table 1), deer exclusion cages were set up to protect the remaining plants.

In addition to larval host plants, a necessary habitat component for many Lepidoptera is nectar sources for adults. Some important larval host plants for rare shrubland Lepidoptera are also important nectar sources: many spring butterflies nectar at lowbush blueberries, and New Jersey tea is used by a wide variety of butterflies that fly during the summer. The availability of nectar has been suggested as a factor in the decline of some populations of the Karner blue (US Fish and Wildlife Service, 2001). Fortunately, most species of Lepidoptera are generalists in their choice of nectar plants. For example, more than 70 different nectar plants have been recorded for secondgeneration adults of the Karner blue (Haack, 1993). Because most moths are nocturnal their adult food sources are less well known, and most species probably do not routinely visit flowers. Some moths, including all species of Saturniidae, Mimallonidae, and Lasiocampidae, and many Notodontidae and Arctiidae, do not feed at all as adults (Scoble, 1992; Wagner, 2000).

Active management may not be required for all shrublands. Some natural communities have self-sustaining properties resulting from both inherent biological characteristics and the chemical and physical parameters of the environments in which they occur. Thus "alternate community states" may persist indefinitely in the absence of disturbance severe enough in spatial and temporal scale to switch the system to an alternate state (Petraitis and Latham, 1999). In North America, heathlands interspersed within a primarily forested landscape may represent an example of such alternate community states. Ericaceous vegetation acidifies the soil and contributes litter that is chemically inert and slow to decompose; microbial decomposition is further slowed by the cool climate of bogs, frost pockets, and ridgetops where such heathlands tend to occur. Slowed decomposition results in low availability of nitrogen, limiting the establishment and growth of many plants. Ericaceous plants are not so limited because symbiotic micorrhizal fungi facilitate uptake of nitrogen in chemical forms unavailable to most plants (Petraitis and Latham, 1999). In such systems, severe fire during drought conditions is the most likely disturbance of sufficient scale to switch from forest to heathland; subsequently, the edaphic properties and inherent flammability of the heathland community will result in frequent, low-intensity fires that maintain it indefinitely. In the absence of low-intensity disturbance (e.g., if fires are actively suppressed by humans), a gradual transition from heathland to forest may be expected.

Within pitch pine-scrub oak barrens, inherent selfmaintaining properties are not limited to the heath vegetation. Microclimate may maintain the open structure of scrub oak thickets and other barrens vegetation for a longer period of time than would be expected in the absence of disturbance. For example, pine barrens in eastern Maine studied by Winne (1997) have remained open since a major fire approximately 1700 years ago. On level, xeric sandplains (and especially in frost pockets) with rapid radiational cooling and lack of sufficient canopy cover or soil moisture to prevent heat loss, scrub oak thickets are exposed to late spring frosts that often result in dieback of sprouting leaves, as well as a shorter growing season that results in a slow growth rate and reduced stem height (Motzkin et al., 2002a). Thus feedback mechanisms between vegetation structure and frost damage slow the establishment of a forest canopy even in the absence of frequent fire or other disturbance.

\subsection{Research needs}

We have reviewed the natural history of the rarer shrubland Lepidoptera of southern New England and southeastern New York in the hope that these organisms will become increasingly appreciated as "focal species" (Lambeck, 1997) to evaluate and inform conservation and management efforts for pitch pine-scrub oak barrens and other native shrublands. However, it must be acknowledged that solving practical conservation problems is impossible without basic factual knowledge of organisms, especially taxonomy and autecology (Noss, 1996; Futuyma, 1998; Goldstein, 1999). Although the species-level taxonomy of most adult macro-Lepidoptera is well established, much remains to be explored regarding larval requirements. For example, larval host plants are completely unknown for five (9\%) of the 56 species of rare shrubland Lepidoptera listed in Table 1. Even for species with known larval hosts, growth and survivorship probably differs among particular host 
plants, yet this has received little study. Key population parameters, such as major sources of larval mortality, have not been quantified for most species. Perhaps most fundamental to any serious attempt at conservation planning for rare Lepidoptera, a knowledge of precise habitat requirements and the amount and configuration of habitat required to maintain viable populations and metapopulations are still largely unknown. Finally, management type and intensity and season and frequency of application have not been investigated with regard to specific effects on populations of rare pitch pine-scrub oak barrens Lepidoptera.

\section{Acknowledgements}

Paul Goldstein (Field Museum of Natural History), Tim McCabe (New York State Museum), Mark Mello (Lloyd Center for Environmental Studies), and Tim Simmons (Massachusetts Natural Heritage and Endangered Species Program) have shared data, literature, and countless observations. Monty Volovsky and several other students ran and sorted blacklight samples and collected caterpillars that contributed greatly to our knowledge of the region's fauna. Tim Simmons provided comments that considerably improved the habitat management section of this paper. Financial support to DLW came from contract grants from the Connecticut and Massachusetts Chapters of The Nature Conservancy and the Connecticut Department of Environmental Protection's income tax check-off fund. Support for MWN was provided by the Natural Heritage and Endangered Species Program of the Massachusetts Division of Fisheries and Wildlife, and some of the data presented in this paper were initially compiled as part of the BioMap project funded by the Massachusetts Executive Office of Environmental Affairs. The Edward C. Childs family provided summer support and lodging for our work in Litchfield County, Connecticut.

\section{References}

Aizen, M.A., Patterson, W.A., 1995. Leaf phenology and herbivory along a temperature gradient: a spatial test of the phenological window hypothesis. J. Veg. Sci. 6, 543-550.
Arnaud Jr., P.H., 1978. A Host-Parasite Catalog of North American Tachinidae (Diptera). Publication No. 1319. US Science and Education Administration, Washington, DC.

Awmack, C.S., Leather, S.R., 2002. Host plant quality and fecundity in herbivorous insects. Annu. Rev. Entomol. 47, 817-844.

Barbour, H., Simmons, T., Swain, P., Woolsey, H., 1998. Our Irreplaceable Heritage: Protecting Biodiversity in Massachusetts. Massachusetts Natural Heritage and Endangered Species Program, Massachusetts Division of Fisheries and Wildlife, Westborough, Massachusetts, and The Nature Conservancy, Massachusetts Chapter, Boston, MA.

Boettner, G.H., Elkinton, J.S., Boettner, C.J., 2000. Effects of a biological control introduction on three nontarget native species of saturniid moths. Cons. Biol. 14, 1798-1806.

Boyd, H.P., 1978. The tiger beetles (Coleoptera: Cicindelidae) of New Jersey with special reference to their ecological relationships. Trans. Am. Entomol. Soc. 104, 191-242.

Bromley, S.W., 1946. Guide to the Insects of Connecticut. Part VI. Asilidae. Connecticut State Geology and National History Survey Bulletin No. 69, Hartford, CT.

Christensen, N.L., 1985. Shrubland fire regimes and their evolutionary consequences. In: Pickett, S.T.A., White, P.S. (Eds.), The Ecology of Natural Disturbance and Patch Dynamics. Academic Press, Orlando, FL, pp. 85-100.

Covell, C.V., 1984. A Field Guide to the Moths of Eastern North America. Houghton Mifflin, Boston, MA.

Creighton, W.S., 1950. The Ants of North America. Bulletin of the Museum of Comparative Zoology, vol. 104. Harvard University, Cambridge, MA.

Cryan, J., 1985. Retreat in the barrens. Defenders of Wildlife (January-February), pp. 18-19.

CT DEP, 1998. Connecticut's Endangered, Threatened and Special Concern Species. Public Act 224. State of Connecticut Department of Environmental Protection, Hartford, CT.

Davis, M.B., Spear, R.W., Shane, L.C.K., 1980. Holocene climate of New England. Quat. Res. 14, 240-250.

Donohue, K., Foster, D.R., Motzkin, G., 2000. Effects of the past and the present on species distribution: land-use history and demography of wintergreen. J. Ecol. 88, 303-316.

Feeney, P., 1970. Seasonal changes in oak leaf tannins and nutrients as a cause of spring feeding by winter moth caterpillars. Ecology 51, 565-581.

Ferguson, D.C., 1975. Host records for Lepidoptera reared in eastern North America. Technical Bulletin No. 1521. USDA, Washington, DC.

Foil, L.D., Hardy, T.N., Johnson, S.J., Church, G.E., Hammond, A.M., 1991. Effect of leaf age and photoperiod on buck moth (Lepidoptera: Saturniidae) larval and pupal development. J. Entomol. Sci. 26, 312-319.

Forbes, W.T.M., 1923. Lepidoptera of New York and Neighboring States. Part I. Memoir No. 68. Cornell University Agriculture Experimental Station, Ithaca, NY.

Forbes, W.T.M., 1948. Lepidoptera of New York and Neighboring States. Part II. Memoir No. 274. Cornell University Agriculture Experimental Station, Ithaca, NY. 
Forbes, W.T.M., 1954. Lepidoptera of New York and Neighboring States. Part III. Memoir No. 329. Cornell University Agriculture Experimental Station, Ithaca, NY.

Forbes, W.T.M., 1960. Lepidoptera of New York and Neighboring States. Part IV. Memoir No. 371. Cornell University Agriculture Experimental Station, Ithaca, NY.

Foster, D.R., 2002. Thoreau's country: a historical-ecological perspective on conservation in the New England landscape. J. Biogeogr. 29, 1537-1555.

Foster, D.R., Motzkin, G., 1999. Historical influences on the landscape of Martha's Vineyard: perspectives on the management of Manuel F. Correllus State Forest. Harvard Forest Paper No. 23. Harvard Forest, Petersham, MA.

Foster, D.R., Hall, B., Barry, S., Clayden, S., Parshall, T., 2002. Cultural, environmental, and historical controls of vegetation patterns and the modern conservation setting on the island of Martha's Vineyard, USA. J. Biogeogr. 29, 1381-1400.

Futuyma, D.J., 1998. Wherefore and whither the naturalist? Am. Nat. 151, 1-6.

Givnish, T., Menges, E., Schweitzer, D.F., 1988. Minimum area requirements for long term conservation of the Albany pine bush and Karner blue butterfly. Consultants' Report Prepared for the City of Albany. Malcolm Pirnie, White Plains, New York.

Goldstein, P.Z., 1992a. Survey for Lepidoptera and Formicidae at Manuel F. Correllus State Forest and nearby areas, Dukes County, Massachusetts. Report to the Massachusetts Natural Heritage and Endangered Species Program, Massachusetts Division of Fisheries and Wildlife, Westborough, MA.

Goldstein, P.Z., 1992b. Informative occurrences of insects in the Manuel F. Correllus State Forest, Martha's Vineyard Island, Massachusetts: comments and management recommendations. Report to the Massachusetts Natural Heritage and Endangered Species Program, Massachusetts Division of Fisheries and Wildlife, Westborough, MA.

Goldstein, P.Z., 1994. Update of rare insect occurrences in the Manuel F. Correllus State Forest and vicinity, Martha's Vineyard, Dukes County, Massachusetts, USA: Documentation of regionally rare insects and management recommendations. Report to the Massachusetts Natural Heritage and Endangered Species Program, Massachusetts Division of Fisheries and Wildlife, Westborough, MA.

Goldstein, P.Z., 1997. Lepidopteran assemblages and the management of sandplain communities on Martha's Vineyard, Massachusetts. In: Vickery, P.D., Dunwiddie, P.W. (Eds.), Grasslands of Northeastern North America. Massachusetts Audubon Society, Lincoln, MA, pp. 217-236.

Goldstein, P.Z., 1999. Functional ecosystems and biodiversity buzzwords. Cons. Biol. 13, 247-255.

Goldstein, P.Z., Simmons, T., 2002. A checklist and commentary on the scarabaeid fauna of the Massachusetts offshore islands (Coleoptera: Scarabaeidae). J. New York Entomol. Soc. 110, 389-461.

Haack, R.A., 1993. The endangered Karner blue butterfly (Lepidoptera: Lycaenidae): biology, management considerations, and data gaps. In: Gillespie, A.R., Parker, G.R., Pope, P.E., Rink, G. (Eds.), Proceedings of the Ninth Central
Hardwood Forest Conference. General Technical Report No. NC-161. USDA, Washington, DC, pp. 83-100.

Handfield, L., 1999. Le Guide des Papillons du Quebec. Broquet, Boucherville, Quebec, Canada.

Kirby, P., 2001. Habitat Management for Invertebrates. UK Joint Nature Conservation Committee and the Royal Society for the Protection of Birds, Bedfordshire, UK.

Klots, A.B., 1951. A Field Guide to the Butterflies of North America East of the Great Plains. Houghton Mifflin, Boston, MA.

Knisley, C.B., Schultz, T.D., 1997. The Biology of Tiger Beetles and a Guide to the Species of the South Atlantic States. Special Publication No. 5. Virginia Museum of Natural History, Martinsville, VA.

Lambeck, R.J., 1997. Focal species: a multi-species umbrella for nature conservation. Cons. Biol. 11, 849-856.

Lorimer, C.G., White, A.S., 2003. Scale and frequency of natural disturbances in the northeastern United States: implications for early-successional forest habitat and regional age distributions. For. Ecol. Manage. 185, 41-64.

MA DFW, 2003. Massachusetts List of Endangered, Threatened and Special Concern Species. Section 10.60 of Chapter 321 of the Code of Massachusetts Regulations. Massachusetts Division of Fisheries and Wildlife, Westborough, MA.

McCabe, T.L., 1995. The changing insect fauna of Albany's pine barrens. In: LaRoe, E.T., Farris, G.S., Puckett, C.E., Doran, P.D., Mac, M.J. (Eds.), Our Living Resources: A Report to the Nation on the Distribution, Abundance, and Health of US Plants, Animals, and Ecosystems. US Dept. Int., National Biological Survey, Washington, DC, pp. 166-168.

McCabe, T.L., Weber, C.N., 1994. The robber flies (Diptera: Asilidae) of the Albany Pine Bush. Great Lakes Entomol. 27, 157-159.

Motzkin, G., Foster, D.R., 2002. Grasslands, heathlands and shrublands in coastal New England: historical interpretations and approaches to conservation. J. Biogeogr. 29, 1569-1590.

Motzkin, G., Patterson, W.A., Foster, D.R., 1999. A historical perspective on pitch pine-scrub oak communities in the Connecticut Valley of Massachusetts. Ecosystems 2, 255-273.

Motzkin, G., Ciccarello, S.C., Foster, D.R., 2002a. Frost pockets on a level sand plain: does variation in microclimate help maintain persistent vegetation patterns? J. Torrey Bot. Soc. 129, 154-163.

Motzkin, G., Eberhardt, R., Hall, B., Foster, D.R., Harrod, J., MacDonald, D., 2002b. Vegetation variation across Cape Cod, Massachusetts: environmental and historical determinants. J. Biogeogr. 29, 1439-1454.

Motzkin, G., Orwig, D.A., Foster, D.R., 2002c. Vegetation and disturbance history of a rare dwarf pitch pine community in western New England, USA. J. Biogeogr. 29, 1455-1467.

NatureServe, 2003. NatureServe Explorer: An Online Encyclopedia of Life [web application], Version 1.6. Arlington, VA. http://www.natureserve.org/explorer.

New, T.R., 1997. Butterfly Conservation, 2nd ed. Oxford University Press, South Melbourne, Australia.

Noss, R.F., 1996. The naturalists are dying off. Cons. Biol. 10, 1-3. Parshall, T., Foster, D.R., 2002. Fire on the New England 
landscape: regional and temporal variation, cultural and environmental controls. J. Biogeogr. 29, 1305-1317.

Petraitis, P.S., Latham, R.E., 1999. The importance of scale in testing the origins of alternative community states. Ecology 80 , 429-442.

Riotte, J.C.E., 1980. Sphinx poecila: a valid North American hawkmoth species (Lepidoptera: Sphingidae). Great Lakes Entomol. 13, 115-130.

Schaffner Jr., J.V., 1959. Microlepidoptera and their parasites reared from field collections. USDA, Miscellaneous Publication No. 767, Washington, DC.

Schaffner, J.V., Griswold, C.L., 1934. Macrolepidoptera and their parasites reared from field collections in the northeastern part of the United States. USDA Miscellaneous Publication No. 188, Washington, DC.

Schowalter, T.D., 1985. Adaptations of insects to disturbance. In: Pickett, S.T.A., White, P.S. (Eds.), The Ecology of Natural Disturbance and Patch Dynamics. Academic Press, Orlando, FL, pp. 235-252.

Schweitzer, D.F., 1994. Prioritizing Karner blue butterfly habitats for protection activities. In: Andow, D.A., Baker, R.J., Lane, C.P. (Eds.), The Karner Blue Butterfly: A Symbol of a Vanishing Landscape. Miscellaneous Publication No. 841994. Minnesota Agriculture Experimental Station, St. Paul, MN, pp. 173-183.

Schweitzer, D.F., Rawinski, T.J., 1987. TNC element stewardship abstract: northeastern pitch pine-scrub oak barrens. The Nature Conservancy, Eastern Heritage Task Force, Boston, MA.

Scoble, M.J., 1992. The Lepidoptera: Form, Function, and Diversity. Oxford University Press, Oxford, UK.

Slansky, F., 1993. Nutritional ecology: the fundamental quest for nutrients. In: Stamp, N.E., Casey, T.M. (Eds.), Caterpillars: Ecological and Evolutionary Constraints on Foraging. Chapman \& Hall, New York, pp. 29-91.
Thomas, C.D., Jones, T.M., 1993. Partial recovery of a skipper butterfly (Hesperia comma) from population refuges: lessons for conservation in a fragmented landscape. J. Anim. Ecol. 62, 472-481.

Tietz, H.M., 1972. An Index to the Described Life Histories, Early Stages, and Hosts of the Macrolepidoptera of the Continental United States and Canada. The Allyn Museum of Entomology, Sarasota, FL.

US Fish and Wildlife Service, 2001. Karner Blue butterfly (Lycaeides melissa samuelis) technical/agency draft recovery plan. Fort Snelling, MN.

Wagner, D.L., 2000. Moths. In: Levin, S.A. (Ed.), The Encyclopedia of Biodiversity. Academic Press, San Diego, CA, pp. 249-270.

Wagner, D.L., 2004. Butterfly study in Connecticut. In: O'Donnell, J.E., Gall, L.F. (Eds.), Connecticut Butterfly Atlas. Connecticut Department of Environmental Protection, Hartford, CT.

Wagner, D.L., Ferguson, D.C., McCabe, T.L., Reardon, R.C., 2001. Geometroid Caterpillars of Northeastern and Appalachian Forests. USFS, Tech. Trans. Bull. FHTET-2001-10. USDA, Washington, DC.

Webber, R.T., Schaffner Jr., J.V., 1926. Host relations of Compsilura concinnata Meigen, an important tachinid parasite of the gypsy moth and the brown-tail moth. Bulletin No. 1363. USDA, Washington, DC.

Williams, D.W., Fuester, R.W., Metterhouse, W.W., Balaam, R.J., Bullock, R.H., Chianese, R.J., Reardon, R.C., 1992. Incidence and ecological relationships of parasitism in larval populations of Lymantria dispar (Lepidoptera: Lymantriidae). Biol. Contr. 2, 35-43.

Winne, J.C., 1997. History of vegetation and fire on the Pineo Ridge pine grassland barrens of Washington County, Maine. In: Vickery, P.D., Dunwiddie, P.W. (Eds.), Grasslands of Northeastern North America. Massachusetts Audubon Society, Lincoln, MA, pp. 25-52. 